Journal Universitas Muhammadiyah Gresik Engineering, Social Science, and Health International Conference (UMGESHIC)

UMGCINMATIC : $1^{\text {st }}$ Rethinking Education during Covid-19 Era: Challange and Innovation

\title{
EFFECTS OF SMALL-GROUP STUDENT TALK ON THAI \\ UNDERGRADUATE STUDENTS' \\ INDIVIDUAL WRITING PERFORMANCE
}

\author{
Author \\ Massaya Rachawong ${ }^{1}$ \\ ${ }^{1}$ Loei Rajabhat University, Thailand
}

Email: massayaracha@gmail.com

\begin{abstract}
This quasi-experimental study, included a pretest and a posttest, aimed to investigate the effects of small-group student talk on Thai undergraduate students' individual writing performance. The participants of the study were 34 second-year English majored students at Loei Rajabhat University. They were randomly assigned to an experimental group and a control group to investigate whether employing small-group student talk would effectively facilitate students' individual writing performance. The participants in the experimental group were divided into a small group of four for planning during a prewriting task, while the participants in the control group worked individually. The effects after the quasi-experimental study were measured by the analytic scores on five components of the writing task and the holistic writing scores cumulated of all these components. Statistical analyses revealed that the two groups were significantly distinguished by the analytic and holistic scores, indicating that participants in the experimental group performed better than peers in the control group. The effects of small-group student talk were found statistically significant in facilitating students' writing improvement in all five aspects: content, organization, vocabulary, and language use, mechanics.
\end{abstract}

\section{Keywords: Small talk, Student talk, and Writing Performance}

\section{INTRODUCTION}

In the context of education, writing becomes an important skill to learn, because it is a part of four featured skills that must be mastered well by learners, but it is not easy to master this skill. Although learners are familiar with writing, there are many crucial points that make writing not as easy as it is assumed. For example, when students are asked to write a short story, they are expected to consider at least the content, organization, vocabulary, punctuation, and grammar. It demands them to learn this skill deeper before producing their writings (Wibowo, 2013). Writing in a university has been regarded as one of the complex English skills that require thoroughly ways in order to produce a highly rich piece of writing. It is not 
only about producing a grammatically correct piece of writing, but the writing should show a well communicative writing that can deliver what the writer intended to convey (Qamariah, 2021).

When writing, unlike paired writing tasks where learners work together to co-construct a single text with joint authorship, prewriting discussions provide learners opportunities for interacting during the planning stage only, after that, learners will compose individually (Storch, 2013). Prewriting discussions are the most commonly used among pair and small group activities in L2 writing settings (Fernandez Dobao, 2012). Similar to individual prewriting, Neumann \& McDonough (2015) mentioned that prewriting discussions help learners brainstorm ideas and organize their ideas into a writing plan. They may help learners generate L2 words and expressions to use in their texts (Kang \& Lee, 2019).

In the collaborative writing group, talk creates opportunities for learners to help each other with their writing by talking to one another. The learners act as analytical and critical responders or friends, so that they can be familiar with using talks in the process of developing their writing skills (Rubin, 1990). Talk generates and supports the development and the articulation of ideas for writing followed by the act of transforming the thoughts and ideas into texts (Parr, Jesson, \& McNaughton 2009).

Small-group student talk, regarded as one of the ways for achieving the goal in enabling students' writing development, is the meaningful discussion among students in small groups who talk about writing tasks followed by their individual writing ( $\mathrm{Li}$, Zhang, \& Parr, 2020). Present studies of L2 writing have seen small-group student talk being used increasingly for improving students' writing ability. Exploring student talk in the form of dialogues among peers during collaborative writing tasks when students co-author their written texts is one strand of such research. Some of the studies have documented the nature of such dialogue by focusing on either group dynamics in terms of patterns of interaction (Kim \& McDonough, 2008). Others have analyzed the effects of student talk on collaborative writing by comparing the co-constructed written texts with those independently produced (McDonough, Vleeschauwer, \& Crawford, 2018; Storch \& Wigglesworth, 2007)

Although there are a number of studies has surveyed learners' perceptions of peer feedback interactions, less attention has been paid to small-group student talk before writing individually, especially when using small-group student talk to plan for L2 individual writing. Therefore, this study aimed to bridge the gap mentioned above adopting a quasi-experimental design with a pretest and posttest to state whether small-group student talk, used as a collaborative prewriting discussion, has effects on Thai undergraduate students' individual writing performance.

\section{METHOD}

a. Research paradigm and design 
In this study, a quasi-experimental research design was adopted. Participants was randomly assigned to two groups: an experimental group and a control group. The participants in the experimental group were divided into a small group of four for planning during a prewriting task while the participants in the control group work individually.

b. Participants and settings

The study was conducted in Loei Rajabhat University in the northeastern part of Thailand where an Essay Writing course was offered to second-year English majored students. This course aimed to improve students' competence in English writing of different type and train the students to take a critical view of what they were discussing and writing about. The course spanned one semester in the university and was conducted in the second semester in academic year 2020. All the participants in the study were selected using convenience sampling. They were 34 second-year English majored students from two intact groups. All of them had passed the Fundamental Writing course before enrolling in the Essay Writing course in the second semester of their first year. Following the ethics requirements for keeping the participants anonymous and confidential, the participant names were not presented in this study.

c. Instruments/techniques

Narrative essay writing was selected as the genre for the writing tests because it has been one of the major themes in humanistic and social thought since the mid-twentieth century, and it was thought to be the most universal genre (Hatch, 1992). Not only that, but it is also known in every culture, and its template is also universal (Schiffrin, Tannen, \& Hamilton, 2006; Hatch, 1992). A narrative is assumed to be familiar to the participants, and it is, therefore, an important genre for students to learn and to practice to write. All the participants took part in the pretest and the posttest with the same writing tasks. All the two tests were administrated by the researcher. In order to obtain data on the participants' real English writing performance, no external resources were allowed during each test. Besides, the writing prompt, test time, and procedures were constant in both groups of the participants regarding the pretest and the posttest.

d. Data Collection Procedure

Both groups met the instructor in a regular classroom setting. For narrative essay writing, each of them had a three-hour session per week with a total of 3 weeks. Both groups followed the same teaching plan. They were given the instruction about what they had to write. Then, the researcher collected the students' written products to analyse.

e. Data Analysis

The writing rubric developed by Jacobs et al (1981) was used to rate and determine the overall quality of students' written products, both holistically and analytically. The 
rubric comprised five component areas, including content, organization, vocabulary, language use, and mechanics. Each component consisted of four bands: excellent to very good, good to average, fair to poor, and very poor. Three raters holding their MA. degrees related to English Language Teaching were asked to rate all the written products without knowing which group of students they rated. Then independentsamples t-tests were applied to investigate whether there were any effects of smallgroup student talk on students' individual writing performance in terms of the overall quality and the quality of narrative between the experimental group and the control group.

f. Theoritical Framework

To investigate the effects of small-group student talk, this study was framed in Sociocultural Theory (Vygotsky, 1978 as cited in Li, Zhang, \& Parr, 2020) which theorizes that knowledge is constructed by the group, and individual constructs are transformed as a result of group interaction.

g. Significance of the StudY

The researcher expects that this quantitative study will be able to give input to teachers, who teach English, to improve their techniques and approaches in teaching essay writing to their students. In addition, the teachers will be able to figure out what they should focus on when teaching writing. Secondly, it is also expected to the students to be more careful to their writings, and understand about a good writing should be.

\section{RESULT AND DISCUSSION}

According to the research purpose and question, descriptive statistics of students' scores between the experimental group and the control group across the tests were calculated. To check the conditions of the two groups at the beginning of the experiment, independent samples t-tests were used.

\begin{tabular}{|l|l|l|l|l|l|}
\hline \multirow{2}{*}{ Measures } & \multirow{2}{*}{ Group } & \multicolumn{2}{c|}{ Pretest } & \multicolumn{2}{c|}{ Posttest } \\
\cline { 3 - 6 } & & \multicolumn{1}{c|}{ Mean } & \multicolumn{1}{c|}{ S.D. } & \multicolumn{1}{c|}{ Mean } & S.D. \\
\hline \multirow{2}{*}{ Content (30) } & EG & 18.21 & 3.70 & 24.28 & 0.97 \\
\cline { 2 - 6 } & CG & 18.54 & 3.42 & 21.05 & 1.23 \\
\hline \multirow{2}{*}{ Organization (20) } & EG & 14.67 & 3.27 & 17.66 & 0.36 \\
\cline { 2 - 6 } & CG & 14.32 & 3.56 & 14.57 & 0.89 \\
\hline Vocabulary (20) & EG & 15.75 & 1.23 & 18.21 & 2.57 \\
\cline { 2 - 6 } & CG & 15.87 & 1.56 & 15.03 & 2.94 \\
\hline \multirow{2}{*}{ Language Use (20) } & EG & 12.14 & 1.08 & 16.87 & 2.72 \\
\cline { 2 - 6 } & CG & 12.17 & 1.72 & 13.43 & 2.79 \\
\hline & EG & 4.03 & 1.04 & 6.42 & 0.51 \\
\cline { 2 - 6 } & CG & 4.11 & 1.06 & 4.78 & 1.09 \\
\hline
\end{tabular}

Table 1 Descriptive statistics for writing quality's analytic scores across tests. EG= Experimental Group, $\mathrm{CG}=$ Control Group 


\begin{tabular}{|l|c|c|c|c|c|}
\hline \multicolumn{1}{|c|}{ Essay Writing Scores of two group } & $\mathrm{N}$ & $(\overline{\mathrm{X}})$ & $\mathrm{S} . \mathrm{D}$. & $\mathrm{t}$ & Sig. \\
\hline Experimental Group & 34 & 83.44 & 1.42 & $12.84 *$ & $.05^{*}$ \\
Control Group & 34 & 68.86 & 1.78 & & \\
\hline
\end{tabular}

$* \mathrm{p}<.05$

Table 2 Descriptive statistics for writing quality's holistic scores across tests.

According to the table 1 and 2 above, it is found that the students in the experimental group got higher scores than the students in the control group in all five aspects: content, organization, vocabulary, and language use, and mechanics with statistically significant at the .05 level.

In this study, the result of statistical analysis indicates that small-group student talk had beneficial effects on students' individual writing performance because students in the experimental group got higher scores in the posttest in all five aspects mention earlier. The finding supports to the results of Neumann and McDonough (2015) that students who collaborated prewriting discussions with classmates gained higher scored than those who worked individually. It is consistent to the study of Kang \& Lee (2019) that collaborative discussion during the prewriting stage may help learners generate L2 words and expressions to use in their texts.

\section{CONCLUSION}

Such a teaching technique, small-group student talk, should be conducted with a longer period than this study has done. This study used only pretest and posttest to find the immediate result. So, in order to test their long-term knowledge, future studies should be taken.

\section{REFERENCES}

Fernandez Dobao, A. (2012). Collaborative writing tasks in the L2 classroom: Comparing group, pair, and individual work. Journal of Second Language Writing, 21, 40-58.

Jacobs, H.L., Zingraf, S.A., Wormuth, D.R., Hartfiel, V.F., \& Hughey, J.B. (1981). Testing ESL composition: a practical approach. Rowley, Massachusetts: Newbury House.

Kang, S., \& Lee, J. H. (2019). Are two heads always better than one? The effects of collaborative planning on L2 writing in relation to task complexity. Journal of Second Language Writing, 45, 61-72.

Kim, Y., \& McDonough, K. (2008). The effect of interlocutor proficiency on the collaborative dialogue between Korean as a second language learners. Lang. Teach. Res. 12, 211-234. doi: 10.1177/1362168807086288 
Li, H. H., Zhang, L. J., \& Parr, J.M. (2020). Small-group student talk before individual writing in tertiary English writing classrooms in China: nature and insights. Frontiers in Psychology, 11(57056):1-16.

McDonough K., De Vleeschauwer J., \& Crawford, W. (2018). Comparing the quality of collaborative writing, collaborative prewriting, and individual texts in a Thai EFL context. System, (74):109-120.

Neumann, H., \& McDonough, K. (2015). Exploring student interaction during collaborative prewriting discussions and its relationship to L2 writing. Journal of Second Language Writing, 27, 84-104.

Parr, J. M., Jesson, R., \& McNaughton, S. (2009). "Agency and platform: the relationships between talk and writing," in R. Beard, D. Myhill, J. Riley, \& M. Nystrand (Eds.), The SAGE Handbook of Writing Development (pp. 246-259). London: Sage. doi: 10.4135/9780857021069.n17

Qamariah, H. (2021). Teaching Writing to EFL University Students: Some Important Issues (Reducing Writer's block and Breakthrough to Better Teaching). Retrieved from https://media.neliti.com/media/publications/217618-teaching-writing-to-efluniversity-stude.pdf

Rubin, D. L. (1990). Introduction: Ways of talking about talking and learning. In Hynds, S., Rubin, D. (Eds.), Perspectives on talk and learning (pp. 1-20). Urbana, IL: National Council of Teachers of English.

Storch, N. (2013). Collaborative writing in L2 classrooms. Bristol, UK: Multilingual Matters.

Storch, N., \& Wigglesworth, G. (2007). Writing tasks: Comparing individual and collaborative writing. In M. del Pilar Garcia-Mayo (Ed.), Investigating tasks in formal language learning. London: Multilingual Matters.

Wibowo, A., B. (2013). Improving Writing Skill by Using Process Writing Approach for Grade X Students of SMA N 1 Kasihan Bantul Yogyakarta in the Academic Year of 2012/2013. Thesis of Sarjana Pendidikan in English Language Education. Yogyakarta State University, Yogyakarta. 